\title{
THE EFFECT OF DISPOSITION ON STUDENT MATHEMATICS \\ LEARNING ACHIEVEMENT IN MEDAN STATE 28 JUNIOR HIGH SCHOOL
}

\author{
Machrani Adi Putri Siregar ${ }^{1 *}$, Eryanti Lisma ${ }^{1}$ \\ ${ }^{1}$ Faculty of Teacher Training and Education, Universitas Muslim Nusantara Al-Washliyah, Medan, Indonesia \\ *Corresponding Author: machrani.adi.putri@gmail.com
}

\begin{abstract}
This study titled as The Effect of Disposition on Student Mathematics Learning Achievement in Medan State 28 Junior High School. In this study, disposition is an independent variable and achievement in mathematics learning is a dependent variable. Mathematical disposition is a change of student's tendency in assuming and behaving toward mathematics, also their act when learning mathematics. For example, when students can solve non-routine problems, their behavior and assumption of mathematics as a student become more positive. The more mathematical concepts understood, the more students convinced that mathematics can be mastered. Based on theory, there are many factors that influence student's achievement in mathematics learning. In this study, researcher only took disposition factor. This research took place at Medan State 28 Junior High School which located at Karya Bersama St. No. 17 Medan Johor. The method of this study is a quantitative method with all of VIII class students which amount to 273 students and divided into 8 (eight) study groups. The data obtained by giving a questionnaire consisting of 19 statements. The data then analyzed by using simple linear regression analysis. The data analysis was performed by using SPSS 21 software for Windows. From the results of this study, it can be concluded that there is an effect of disposition on students' achievement in mathematics learning or in other words, students' achievements in mathematics learning are influenced by the disposition attitudes that students have in mathematics learning. The influence occurs in the disposition of achievement in mathematics learning is positive, that is equal to $6.6 \%$.
\end{abstract}

Keywords: Disposition, Mathematics Learning Achievement.

\section{PRELIMINARY}

Mathematics learning is a part of the process of education in school. If examined carefully, it is very clear that mathematics subjects in each curriculum are always taught in each education unit and at each class level, the lesson has more portion than the other subjects. This shows that education experts and curriculum designers realize that mathematics subjects can meet expectations in the provision of potential human resources (HR) that are reliable, which are humans who have the ability to reason logically, critically, systematically, rationally and accurately; have the ability to be honest, objective, creative and open; has the ability to act effectively and efficiently; and has the ability to work together, so that it has the ability to answer the challenges of the globalization era and the rapid development of Science and Technology at this time and in the future.

In the learning process of mathematics subject, there are many factors that influence student's mathematics learning achievement, one of them is the mathematical disposition of students. Mathematical disposition is the connection and appreciation of mathematics, which is a tendency to think and act in a positive way. Student's disposition towards mathematics is realized through attitudes and actions in choosing an approach in completing tasks. Students' mathematical dispositions are said to be good if the students like problems that are challenges and involve themselves directly in finding or solving problems. In addition, students feel themselves experiencing the learning process when completing the tasks. In the process, students feel the emergence of self-confidence, hope and awareness to look back on the results of their thinking. Mathematical disposition is one of the factors that is seen in determining student learning success. Students need a disposition that will make them persevere in facing more challenging problems, to be responsible for their own learning and to develop good habits in mathematics. Unfortunately, the frequency of teachers tends to reduce the burden of learning mathematics with the intention of helping students, even though it is something important for students.

\subsection{Formulation of The Problem}

This research was conducted to see how dispositions affect students' mathematics learning achievement in Medan Public Middle School 28. 


\subsection{Research purposes}

The purpose of this study was to prove the influence of disposition on mathematics learning achievement of students in Medan Public Middle School 28. In addition, this research is also expected to be able to provide academic information to educators in order to improve student mathematics learning achievement and the quality of education in general.

\section{LITERATURE REVIEW}

\subsection{Disposition}

The National Council of Teacher of Mathematics (NCTM) (1989) states that mathematical disposition is the connection and appreciation of mathematics, which is a tendency to think and act in a positive way. Student's disposition towards mathematics is realized through attitudes and actions in choosing approaches to completing tasks. Is it done with confidence, curiosity in looking for alternatives, diligent, and challenged and the tendency of students to reflect the way they think? Reflection is a way of thinking about what has just been learned or thought back about what has been done in the past. Reflection is a response to events, activities, or new knowledge received (Irianto, 2007: 113). Student's reflections will be seen when students discuss, direct statements about the subject matter that they obtained today, notes, and the results of their work.

Along with the above, Wardani (2008: 15) defines mathematical disposition as an interest and appreciation of mathematics, which is the tendency to think and act positively, including self-confidence, curiosity, perseverance, enthusiasm in learning, persistent problems, flexibility, sharing with others, reflective in doing math. While according to Mulyana (2009: 19) disposition towards mathematics is a change in the tendency of students to look at and behave towards mathematics, and act when learning mathematics. For example, when students can solve non-routine problems, their attitudes and beliefs as a student become more positive. The more mathematical concepts are understood, the more convinced that mathematics can be mastered. According to Sumarmo (2006: 4), mathematical dispositions are desires, awareness, and strong dedication to students to learn mathematics and carry out various mathematical activities.

According to Maxwell (2001), dispositions consist of: (1) inclination, which is how students behave towards tasks; (2) sensitivity, which is how students are prepared to face tasks; and (3) abilities, which is how students focus to complete the task completely; and (4) enjoyment, which is how students behave in completing tasks. Students' mathematical dispositions are said to be good if the students like the problems that are challenges and involve themselves directly in finding / solving problems. In addition, students feel themselves experiencing the learning process when completing the challenge. In the process students feel the emergence of self-confidence, hope and awareness to look back on the results of their thinking. Polking (Syaban, 2008: 32) states that mathematical dispositions include: (1) trust in using mathematics to solve problems, to communicate ideas, and to give reasons; (2) flexibility in investigating mathematical ideas and trying to find alternative methods of solving problems; (3) diligent in working on mathematical assignments; (4) having interest, curiosity, and inventiveness in doing mathematical work; (5) the tendency to monitoring and reflecting on their own performance and reasoning; (6) evaluate the application of mathematics to other situations that arise in mathematics and everyday experience; (7) appreciation of the role of mathematics in culture and value, both mathematics as a tool, and mathematics as a language.

To measure student's mathematical dispositions several indicators are needed. The several indicators stated by NCTM (1989: 233) are:

1) Confidence in solving mathematical problems, communicating ideas, and giving reasons.

2) Flexibility in exploring mathematical ideas and trying various alternative methods to solve problems.

3) Strong determination to complete mathematical tasks.

4) Interest, curiosity, and ability to find in working on mathematics.

5) The tendency to monitor and reflect on one's own thinking and performance processes.

6) Assess mathematical applications in other fields and in everyday life.

7) Appreciation of the role of mathematics in culture and its value, both mathematics as a tool, and mathematics as a language.

While according to Syaban (2008: 33) states, to measure the mathematical disposition of students the indicators used are as follows:

1) Demonstrate passion / enthusiasm in learning mathematics.

2) Demonstrate serious attention in learning mathematics.

3) Showing persistence in dealing with problems.

4) Demonstrate confidence in learning and solving problems.

5) Demonstrate high curiosity.

6) Showing the ability to share with others.

While according to Wardani (2008: 232), aspects measured in mathematical dispositions are (1) self-confidence with indicators of confidence in ability / belief; (2) curiosity consists of four indicators, namely: often asking questions, 
conducting investigations, enthusiasm / enthusiasm in learning, reading / looking for other sources; (3) perseverance with persistent / diligent / attentive / serious indicators; (4) flexibility, which consists of three indicators, which is: cooperation / knowledge sharing, respecting different opinions, trying to find other solutions / strategies; (5) reflective, consisting of two indicators, namely acting and relating to mathematics, liking / feeling happy to mathematics.

Based on the indicators of mathematical disposition stated above, indicators of mathematical disposition can be concluded as (1) confidence in solving mathematical problems, communicating ideas, and giving reasons; (2) flexible in exploring mathematical ideas and trying various methods to solve problems; (3) determined to complete mathematical tasks; (4) interest and curiosity to find something new in doing mathematics; (5) the tendency to monitor and reflect on thought processes and performance; (6) applying mathematics in other fields and in daily life; and (7) appreciation of the role of mathematics in culture and value, both mathematics as a tool, and mathematics as a language.

To express student's mathematical dispositions, it can be done by making a disposition scale and observation. The disposition scale contains the statements of each disposition component. For example, "for deeper understanding, I try to solve math problems in other ways". Through observation, the disposition of students can be known whether there are changes when students get or do assignments. For example, when the learning process is in progress it can be seen whether students solve math problems that are difficult for students to keep trying so that they get the right answer.

There is a strong relationship between mathematical disposition and learning. Mathematics learning in addition to improving student's mathematical thinking or cognitive aspects, must also pay attention to the affective aspects of students, which is mathematical dispositions. Mathematical learning in the classroom must be specifically designed so that in addition to being able to improve student learning achievement. It can also improve mathematical dispositions. Furthermore, NCTM (2000) states that students' attitudes in facing mathematics and their beliefs can influence their achievements in mathematics.

Mathematical disposition is one of the factors that determine the success of student learning. Students need a disposition that will make them persevere in facing more challenging problems, to be responsible for their own learning, and to develop good habits in mathematics. Unfortunately, teachers tend to reduce the burden of learning mathematics with the intention of helping students even though it is something important for students.

Mathematical learning basically adheres to: the principle of learning throughout the verse, the principle of active learning students, and the principle of "learning how to learn". The principle of student learning is active, referring to the notion of learning as something done by students, and not something that is done to students. The statement adheres to the constructivist view that students are individuals who actively build knowledge and are not merely recipients of ready-made information. In the view of constructivism learning is a process, situation, and effort designed by the teacher in such a way as to make students learn according to the principle of learning how to learn. In other words, in learning, teachers act as facilitators, motivators, and learning managers for their students. Then the teacher helps students through accommodation and associations to occur a new balance (role as a facilitator) so that interactions between new information and initial knowledge (unbalanced conditions) occur. Then the teacher helps students through accommodation and asocial a new balance occurs (role as a motivator) so that new knowledge is formed in students. The teacher's activity selects new information (tasks), creates an environment, and motivates students as a whole to describe the role of the teacher as a learning manager.

The United Nations Educational, Scientific and Cultural Organization (UNESCO) details the principle of learning how to learn on the four pillars of education as follows.

1) Learning to understand (learning to know) Learning to understand mathematical knowledge (concepts, principles, ideas, theorems, and relationships between them).

2) Learning to do or learning (learning to do) Learning to carry out the mathematical process (according to the basic mathematical abilities of the school level concerned).

3) Learning to be self (learning to be) Learning to be himself, learning to understand and appreciate mathematical products and processes by showing attitudes of hard work, resilience, discipline, honesty, having motives for achievement and mathematical disposition.

4) Learning to live together. Learning to understand other people, working together, appreciating and understanding different opinions, as well as contributing to each other's opinions.

From some definitions, mathematical dispositions are desires, consciousness, and dedication strong action in students to learn mathematics and carry out various mathematical activities. Having a mathematical disposition is not enough to be shown simply by enjoying learning mathematics. For example, a student likes to study mathematics and he has confidence that in solving mathematical problems there is always only one way and the right answer. Though in mathematics there is not only one way of solving and one correct answer. This shows that just being happy about 
mathematics is not enough? Germany (2006: 131-132), in his research report reveals that Problem Based Learning (PBM) is open and structured PBM has an impact on the formation of positive dispositions of students towards mathematics. The mathematical disposition scale of students who got both of these problem-based learning approaches showed a significant difference. In this case, students who get an open PBM have a mathematical disposition better than those who get a structured PBM. Syaban (2008: 185) about the mathematical disposition of high school students in class X in Bandung, shows that there are significant differences in mathematical dispositions between students who use learning investigative learning and conventional learning. The overall mathematical disposition of students learning using the investigative learning model is better than students who use conventional learning. The results of research on high school students conducted by Wardani (2009: 186), conclude that the mathematical disposition of students studying with Silver inquiry models in groups (ISG) and the Silver model inquiry (ISK) is positive. Student responses in aspects of self-confidence, curiosity, perseverance, flexibility, and reflective are very positive. Most student responses are given to the reflective aspects and flexibility or flexibility. Study Mulyana (2009) about the influence of Knisley's mathematics learning model on improving the mathematical understanding and disposition of high school students in the science program. The results of the study show that overall there are differences in the increase in mathematical understanding and mathematical disposition of students of class IX of the High School which learning uses Knisley's mathematical learning model with students whose learning uses conventional mathematics learning models.

\subsection{Mathematics Learning Achievement}

Learning achievement interpreted as how far the results have been achieved by students in mastering the tasks or subject matter received in a certain period of time. Learning achievement is generally expressed in numbers or letters so that it can be compared with one criterion (Prakosa, 1991).

Learning achievement is a person's ability to achieve high thinking. Learning achievement must have three aspects, namely cognitive, affective and psychomotor. Learning achievement is the best results achieved in a child in education either done or in the scientific field. Learning achievement from students is the result achieved by students obtained from the learning process. Learning achievement is the maximum achievement according to the child's ability at a certain time to something that is done, studied, understood and applied. All education actors (students, parents and teachers) definitely want to achieve a high learning achievement, because high learning achievement is one indicator of the success of the learning process. But in reality, not all students get high learning achievements and there are students who get low learning achievement. The high and low learning achievements obtained by students are influenced by many factors.

Learning achievement is interpreted as the level of student involvement in the teaching and learning process as a result of evaluations conducted by the teacher. Sutratinah Tirtonegoro (1984: 4) suggests that learning achievement is an assessment of the results of business activities that are expressed in the form of numerical symbols, letters or sentences that can reflect the results that have been achieved by each student in a certain period. According to Partini (1980: 49), learning achievement is the result achieved by someone in learning activities. In line with that opinion, Sunarya (1983: 4) states that learning achievement is a change in behavior that includes cognitive, affective and psychomotor domains which is a measure of student success. Haditomo et al (1980: 4) say that learning achievement is a person's ability. Dewa Ketut Sukardi (1983: 51) states that to measure learning achievement using tests, achievement is intended as a tool to reveal actual abilities as a result of learning or learning. According to Sumadi Suryabrata (1987: 324), value is the last formulation that can be given by the teacher regarding the progress or student achievement during a certain period. With report cards, we can find out student achievement. Students with good report cards are said to have high achievements, while those with poor grades are said to be of low learning achievement. Based on the description above, it can be concluded that learning achievement is a measure of the success of student learning activities in mastering a number of subjects during a certain period stated in report cards.

Learning achievement is a measure of success obtained by students during the learning process. Success is determined by various interrelated factors. Dimyati Mahmud (1989: 84-87) said that the factors that influence student learning achievement include internal factors and external factors.

1) Internal factors. Internal factors are factors that come from within the student itself, which consists of N. Ach (Need for Achievement), namely the need or encouragement or motive for achievement.

2) External Factors. External factors are factors that come from outside the student. This can be in the form of infrastructure, environmental conditions both within the family, school and community environment.

In the opinion of Rooijakkers translated by Soenoro (1982: 30), the factors that influence learning achievement are factors that originate from the student and the factors that originate from the teacher. These two factors can be explained as follows:

1) Factors originating from the student (student) these factors include motivation, attention to the subjects that take place, the level of acceptance and remembrance of materials, the ability to apply what is learned, the ability to reproduce and the ability to generalize. 
2) Factors originating from the teacher (Teacher) these factors include the ability to build relationships with the student, the ability to move interest in learning, the ability to provide explanations, the ability to mention the main points taught, the ability to direct attention to ongoing lessons, the ability to respond to reactions.

From the opinion of Rooijakkers about the factors that affect student achievement can be given the conclusion that student achievement is influenced by two factors, namely factors that originate from the student's self and the factors that come from the teacher (teacher). Whereas according to Ngalim Purwanto (1990: 270), factors that influence learning achievement are external factors and internal factors. From the opinion of this expert, it can be explained that the understanding of external factors and internal factors that influence learning achievement are as follows:

1) Factors from outside these external factors are factors that originate from outside the student (students) which includes: a. Natural environment and social environment. b. Instrumentation in the form of curriculum, teacher or teacher, facilities and facilities and administration.

2) Factors from within this internal factor is a factor that originates within the student (student) itself which includes: a. Physiology in the form of physical conditions and sensory conditions, b. Psychology in the form of talent, interest, intelligence, motivation and cognitive abilities.

From some of the opinions of the experts mentioned above, it can be concluded that student learning achievement in general is influenced by two factors, which are the first factor comes from within the student itself and the second factor comes from outside the student who is doing the learning process. Whereas according to Slameto (2003: 54-

72) the factors that influence learning achievement are many types, but can be classified into two, they are:

1) Internal factors, these are factors that exist in the individual who is learning which consists of: 1. Physical factors (health and disability). Psychological factors (intelligence, attention, interest, talent, motives, maturity and readiness). Fatigue factor.

2) External factors, these are factors from outside the individual consisting of: 1. Family factors (the way parents educate, relations between family members, home atmosphere, family economic conditions, understanding of parents, and cultural background). 2. School factors (teacher teaching methods, curriculum, teacher relations with students, student relations with students, school discipline, learning tools, school time, learning standards above size, building conditions, learning methods and homework assignments. 3. Community factors (student activities in society, mass media, associates, and forms of life of society).

According to Muhibbin Shah (2006: 144), student learning achievement is influenced by at least three factors, they are:

1) Internal Factors, which are factors in the learning individual consisting from: 1. Physical factors that include health and disability 2. Psychological factors that include the level of intelligence, attention, interest, talent, motives, maturity and readiness. 3 Factors of fatigue.

2) External factors, which are factors from outside the individual consists of: 1. Family factors, namely the way parents educate, relations between family members, home atmosphere, family economic conditions, understanding of parents, and cultural background. from the school environment, namely teacher teaching methods, curriculum, teacher relations with students, student relations with students, school discipline, learning tools, school time, learning standards above the size, condition of the building, learning methods and homework. Community factors are the activities of students in society, mass media, associates, and forms of community life.

3) Learning Approach Factor (approach to learning), these are the type of student learning efforts that include strategies and methods used by students to conduct learning activities of subject matter. From the description above, it can be concluded that mathematics learning achievement is the result that has been achieved by students in mastering assignments or mathematics learning material received within a certain period of time. So that in this study, the data on students' mathematics learning achievements were obtained from the value of the latest report cards from students who were used as research samples.

\subsection{Location and Time of Research}

The research site in SMP Negeri 28 Medan on Jl. Joint Work No. 17 Medan Johor. The time for research activities starts in May - December 2018.

\section{RESEARCH METHODS AND DESIGN}

The method of this research is quantitative. The research subjects in this study were population. Population is the whole unit or individual within the scope of study, the population is limited as the population or the number of individuals who have at least one common trait (Hadi, 2000). Therefore, the population taken is students of all class VIII SMP Negeri 28 Medan, totaling 273 students and divided into 8 (eight) study groups. The sample of this study uses Purposive Sampling which is the sampling technique used based on certain characteristics or considerations (Arikunto, 2006). Thus, the variables in this study have 2 variables, the independent variable (free) is the disposition and the dependent variable (bound) is the mathematics learning achievement of students. From the explanation above the research design used is the correlation design (associative). 


\subsection{Data Collection Technique}

Thus, to determine the effect of disposition on student achievement in SMP Negeri 28 Medan, a Likert scale questionnaire was used. The disposition questionnaire in this study consisted of 19 statements.

\subsection{Data Analysis}

Based on the design of the study design, the analysis of the data used in this study was Pearson Correlation or Spearman and Kendall's Correlation. Data analysis was performed using the help of SPSS 21 software for Windows.

\section{RESEARCH RESULT}

Based on the results of the analysis, a simple linear regression equation can be made between the disposition variables and the students' mathematics learning achievement variables, namely $\mathrm{Y}=67.566+0.152 \mathrm{X}$. Then this analysis is continued by hypothesis testing, which concludes that there is an effect of disposition on students' mathematics learning achievement. From the output results obtained that the effect of disposition on student mathematics learning achievement is $6.6 \%$ while the rest is influenced by other variables. Then from the results of the correlation test output, it can be seen that there is a significant correlation between disposition variables with students' mathematics learning achievement.

\section{CONCLUSION}

Based on the description of the results of the study, it can be concluded from this study that there is an effect of disposition on student achievement. Or in other words, student learning achievement is influenced by the disposition attitudes that students have in mathematics learning. The influence that occurs between dispositions towards students' mathematics learning achievement is positive at $6.6 \%$ while the rest is influenced by other variables.

\section{BIBLIOGRAPHY}

Arikunto, S., Research Procedure a Practice Approach, (Jakarta: PT Rineka Cipta, 1998).

Arsyad, A., Media Teaching, (Jakarta: PT Raja Grafindo Persada, 2000), Edition I cet 2.

Asnawir and M. Usman, B., Learning Media, (Jakarta: Ciputat Press, 2000).

Azhar, S., Research Methods, (Jogjakarta: Student Library, 1998).

Darajat, Z., Special Methodology for Teaching Islamic Religion, (Jakarta: Bumi Aksara, 1995).

Faisal, S., Basic and Questionnaire Engineering Techniques, (Surabaya: National Business, 1982).

Fulchan, A., Introduction to Research in Education, (Jogjakarta: Student Library, 2004), Ministry of Education and Culture, Large Dictionary of Indonesian Language, (Jakarta: Balai Pustaka, 1998).

Hadi, S., Method Reseach I, (Jogjakarta: Andi Offset, 1989).

Pondia, H., Information and Communication Technology, (Jakarta: Erlangga, 2004).

Sudarto, Philosophy Research Method, (Jakarta: PT. Grafindo Persada, 1997).

Sukirin, Principles of Educational Psychology, (Yogyakarta: Andi Offset, 1979).

Supriyanto, Information and Communication Technology, (Bogor: Yudistira, 2007), [Hamzah B. Uno, Educational Professionals, Educational Problems and Reforms in Indonesia, (Jakarta: PT Bumi Aksara, 2008), edition I cet 3.

Walgito, B., Introduction to General Psychology, (Yogyakarta: Andi Offset, 2004). 